\title{
Korelasi Sikap, Minat, dan Motivasi Belajar dengan Pengetahuan Sejarah Lokal Lampung
}

\section{Yulia Siska}

STKIP PGRI Bandar Lampung

Jl. Khairil Anwar No. 79 Bandar Lampung

Email: yuliasiska1985@gmail.com

\begin{tabular}{|c|c|}
\hline ABSTRACT & ABSTRAK \\
\hline $\begin{array}{l}\text { This study aims to describe the significant } \\
\text { relationship between attitudes, interests, and } \\
\text { motivations with students' knowledge of local } \\
\text { history. This research employed a quantitative } \\
\text { approach with regression analysis. The } \\
\text { population of this study was the } 5 \text { th grade } \\
\text { students of an Elementary School in } \\
\text { Bandarlampung. The number of the sample } \\
\text { was } 53 \text { students. The technique used was } \\
\text { purposive sampling. The research instrument is a } \\
\text { scale of motivation, interests, attitudes, and } \\
\text { knowledge of local history. In analyzing the } \\
\text { data the three predictors regression technique } \\
\text { was used. The results showed that: (1) There is } \\
\text { no relationship between attitude towards Local } \\
\text { History Lesson (X1) with the Local History } \\
\text { Knowledge (Y); (2) There is no correlation } \\
\text { between Interest in Local History Lesson (X2) } \\
\text { with Local History Knowledge (Y); (3) There is a } \\
\text { significant relationship between the Motivation } \\
\text { of Learning Local History (X3) with Local History } \\
\text { Knowledge (Y); and (4) There are a significant } \\
\text { relationship between Attitude (X1), Interests } \\
\text { (X2), and Local Historical Learning Motivation } \\
\text { (X3) along with Local History Knowledge (Y) of } \\
\text { the 5th grade students of an Elementary School } \\
\text { in Bandarlampung. }\end{array}$ & 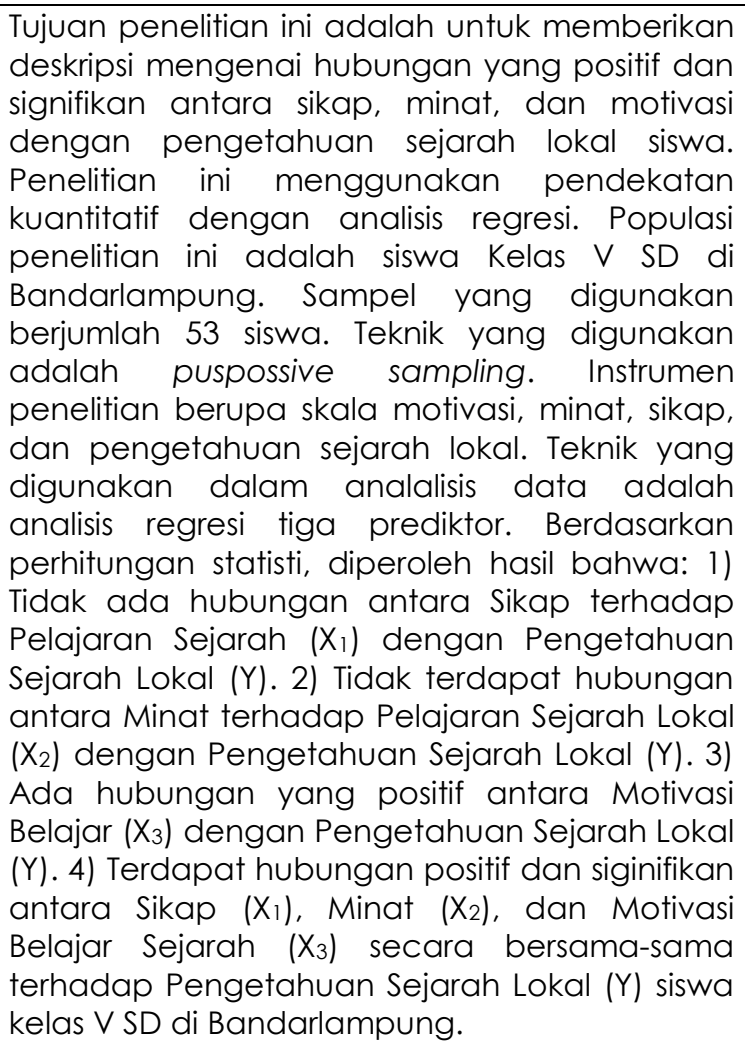 \\
\hline $\begin{array}{l}\text { Keywords: attitude, interests, moti } \\
\text { knowledge of local history. }\end{array}$ & $\begin{array}{l}\text { ata Kunci: sikap, minat, } \\
\text { engetahuan sejarah lokal. }\end{array}$ \\
\hline
\end{tabular}

How to Cite: Siska, Y. (2018). Korelasi Sikap, Minat, dan Motivasi Belajar dengan Pengetahuan Sejarah Lokal Lampung. Mimbar Sekolah Dasar, 5(1), 51-62. doi:http://dx.doi.org/10.17509/mimbar-sd.v5i1.9856.

PENDAHULUAN GUrU mata belajaran sejarah diberi kesempatan untuk mengembangkan materi pelajaran dengan tidak melupakan kondisi sekitar siswa, dalam arti mata pelajaran sejarah yang berimplikasi pada lokalitas sejarah suatu daerah. Salah satu pokok bahasan dalam pembelajaran sejarah di sekolah adalah sejarah lokal yang memiliki tujuan memberikan pengetahuan dan wawasan untuk siswa mengenai nilai-nilai lokal daerah mereka. Materi yang diadopsi dalam sejarah lokal seyogyanya berhubungan dengan nilai kesejarahan lokal di daerah Lampung. Sejarah lokal Lampung memiliki persejajaran yang lekat 
Yulia Siska, Korelasi Sikap, Minat, dan Motivasi Belajar dengan Pengetahuan Sejarah...

dengan lokalitas suatu kelompok masyarakat yang memiliki kekhasan adat, istiadat, budaya, dan sejarahnya. Dengan begitu pengajaran sejarah lokal sangat mendukung dikembangkannya kurikulum yang bermuatan lokal guna mengakrabkan siswa dengan lingkungan sekitar. Dengan begitu, tentu saja akan mengakomodir kepentingan daerah.

Keberhasilan belajar siswa, khususnya pengetahuan sejarah lokal dapat saja bergantung pada dalam diri siswa secara pribadi dan dapat pula mendapat pengaruh dari luar dirinya. Pendapat tersebut sesuai dengan yang diutarakan Sudjana (2005, p. 39) yang menyatakan bahwa "hasil belajar siswa dapat dipengaruhi oleh dua faktor, yaitu faktor dari dalam individu dan faktor yang datang dari luar atau faktor lingkungan". Kedua faktor itu memiliki pengaruh utama terhadap keberhasilan dalam pembelajaran atau prestasi belajar siswa, khususnya pelajaran sejarah. Begitu pun tingkat pengetahuan siswa dapat dijadikan acuan untuk mengetahui prestasi belajar siswa.

Selain pengetahuan, sikap siswa terhadap materi sejarah perlu mendapat perhatian. Hal itu dapat berpengaruh terhadap strategi pembelajaran yang ditentukan guru sehingga pengetahuan siswa menjadi baik. Sikap merupakan semacam kesiapan untuk bereaksi terhadap suatu objek dengan cara tertentu (Azwar, 2012, p. 5). Adapun motivasi atau motif adalah tenaga, energi atau daya yang memiliki sifat kompleks pada diri seseorang untuk menentukan perilaku dalam mencapai tujuan tertentu. Motivasi dapat tumbuh dari dalam diri dan dari lingkungan (Kartadinata, 2010, p. 3; Effendy, 2003, p. 60; Purwanto, 2006, p. 60). Selanjutnya, perilaku motivasi terpengaruh oleh sikap. Bagi Dimyati (2002, p. 54), sikap merupakan suatu motif yang dipelajari. Jika siswa beranggapan bahwa materi atau pelajaran tersebut berarti atau mempunyai makna bagi dirinya maka akan tertarik terhadap materi tersebut sehingga akan menimbulkan kepuasan pada dirinya. Minat siswa terhadap materi sejarah lokal akan menjadi sumber motivasi bagi siswa untuk belajar. Motivasi dalam diri siswa dapat menjamin kelangsungan dari kegiatan belajar dan memberikan arah pada kegiatan belajar (Astuti, 2017). Mengenai minat, Winkel (1983, p. 30) memandang minat merupakan kecenderungan individu yang menetap untuk merasa tertarik, merasa senang pada suatu bidang atau objek tertentu sehingga dapat meningkatkan aktivitasnya. Minat berasal dari rasa tertarik dan menyenangi sebagai dasar untuk memusatkan perhatian dan aktivitas, karena pada dasarnya, perilaku manusia didorong oleh keinginan untuk menghindari kebencian atau ketidaksenangan (preasure principle) (Sukmadinata \& Surya, 1978, p. 20). Perasaan senang tidak saja dapat 
meningkatkan aktivitas, tetapi dapat mengurangi kejenuhan.

Kaitannya dengan proses pembelajaran, belajar sejarah bukan sekadar menghafal fakta. Siswa dapat mengenal bangsanya dengan lebih baik dan mempersiakan kehidupan berbangsanya secara lebih siap untuk jangka waktu selanjutnya (Hasan, 1997, p. 141). Selain itu, Krug (1967, p. 22) berargumen bahwa pengajaran sejarah bangsa merupakan upaya terbaik untuk memperkuat kesatuan dan kesatuan nasionall serta menanamkan semangat cinta tanah air dan jiwa patriot. Dengan demikian, pengajaran sejarah dapat bertindak sebagai penyadaran dan pembangkitan semangat pengabdian yang tinggi dengan penuh tanggung jawab. Kepekaan siswa terhadap sejarah akan melahirkan aspirasi dan inspirasi serta partisipasi dalam melaksanakan tugasnya sebagai warga negara Indonesia yang seutuhnya. Melalui pendidikan sejarah, proses sosialisasi sikap nasionalisme dapat dilaksanakan secara lebih sistematik dan terencana. Dalam upaya mensosialisasikan sikap nasionalisme, strategi pembelajaran sejarah dilakukan dengan tahap pengenalan dan pengetahuan, tahap penerimaan, dan tahap pengintegrasian (Hizam, 2007, p. 289).

Di luar batasan sejarah nasional Indonesia, muncul istilah sejarah lokal yang oleh Abdullah (2010, p.15) diartikan sebagai sejarah dari suatu tempat, suatu locality yang batasannya ditetnukan oleh penulis sejarah. Sejarah lokal memiliki sifat elastis, dapat membahas mengenai suatu desa, kecamatan, kabupaten, tempat tinggal suatu etnis, suku bangsa yang ada dalam suatu daerah atau beberapa daerah. Dari dasar itulah, Priyadi (2012, pp. 2-6) mengajukan konsep sejarah lokal sebagai unit administratif politis, kesatuan etnis-kultural, unit administratif sebagai suatu kumpulan etniskultural, kesadaran sejarah, sejarah lokal dalam istilah netral dan tunggal. Pendapat tersebut mengacu pada perspektif yang diungkap Lightman \& French (1978, p.169), yaitu sejarah lokal untuk kepentingan sendiri, menguji hipotesis tentang jurisdiksi yang lebih luas, negara atau bangsa, dan sejarah lokal yang fokus pada pengetahuan masyarakat sebagai proses perkembangan masyarakat yang tumbuh dan berkembang. Meskipun secara analitis berbeda, dalam praktik yang sebenarnya, titik singgung ini sering silang pengertian dan dapat pula berjalan seiring.

Begitu pun Supardi (2014, pp. 91-99) dalam studinya menganggap pengajaran sejarah lokal mempunyai peran besar dalam upaya menghadirkan peristiwa kesejarahan yang dekat pada siswa. Elastisitas sejarah lokal mampu menghadirkan berbagai fenomena, baik berkaitan mulai dari latar belakang kelvarga (family history), sejarah sosial dalam lingkup lokal, peranan pahlawan 
Yulia Siska, Korelasi Sikap, Minat, dan Motivasi Belajar dengan Pengetahuan Sejarah...

lokal dalam perjuangan lokal maupun nasional, kebudayaan lokal, asal-usul suatu etnis, dan berbagai peristiwa yang terjadi pada tingkat lokal. Sejarah lokal telah mampu mengelaborasi kejadian di masa lampau dalam konteks lokal. Sejarah lokal dalam konsep mikro telah menampakkan dasar-dasar dinamikanya sehingga peristiwa sejarah dapat diungkap melalui dinamika internal di tiap daerah sebagai sesuatu yang otonom dan khas.

Pengajaran materi sejarah lokal dalam pendidikan dasar dapat dilaksanakan melalui berbagai cara sebagai berikut. Pertama, dengan cara menyisipkan pada beberapa topik sejarah nasional yang memiliki kaitan dengan peristiwa sejarah lokal. Kedua, melalui studi khusus terhadap objek sejarah, seperti peninggalan sejarah, museum, dan perpustakaan (Widja, 1989, p.141). Ketiga, dengan cara team teaching. Guru IPS dapat melakukan kolaborasi untuk membahas masalah lokal secara interdisipliner. Pengajaran sejarah lokal di sekolah juga dapat menghadirkan realita atas fenomena pada lokalitas lainnya. Hal ini dianggap penting sebagai upaya berempati dan mengerti tehadap keberagaman budaya lain (Supardi, 2006, p. 117-137).

Berikut penelitian yang pernah dilakukan terkait beberapa variabel yang berpengaruh terhadap pengetahuan sejarah lokal di antaranya adalah motivasi, minat, dan sikap.

Handayani (2008) mengkaji hubungan antara pengetahuan, sikap, minat, motivasi belajar dengan prestasi belajar. Terdapat empat variabel bebas (pengetahuan, sikap, minat, dan motivasi) dan satu variabel terikat, yaitu prestasi belajar. Hal yang menjadi pembeda adalah pada variabel bebas yang dipilih dan subjek kajian pada variabel terikat, yaitu prestasi belajar mata kuliah KDM I. Penelitian selanjutnya dilakukan oleh Saifullah (2009) yang mencari pengaruh sikap, minat dan motivasi belajar terhadap prestasi bahasa Arab kelas IV SD. Variabel terikat memiliki perbedaan objek kajian, yaitu prestasi bahasa Arab. Begitu pula dengan kajian yang dilakukan Ruslaeni, dkk. (2013), yaitu pengaruh minat belajar, gaya mengajar dan sikap disiplin terhadap prestasi belajar siswa sekolah dasar. Ada perbedaan mencolok dengan penelitian ini, yaitu perbedaan pada salah satu variabel bebas, yaitu gaya mengajar serta pada variabel terikat yang memiliki cakupan objek yang lebih luas.

Dengan demikian, penelitian yang penulis lakukan belum pernah dikaji sebelumnya. Pemilihan objek kajian pada ranah kognitif, yaitu pengetahuan sejarah lokal masih belum tersentuh oleh peneliti lain. Oleh sebab itu, novelty dari penelitian ini terletak pada variabel bebas dan terikat 
yang secara bersama-sama belum pernah dikaji sebelumnya.

Terkait dengan latar belakang masalah yang telah diungkap sebelumnya, berikut adalah tujuan dari penelitian ini, yaitu untuk: (1) mendeskripsikan hubungan yang positif yang signifikan antara sikap siswa dengan pengetahuan sejarah lokal; (2) mendeskripsikan hubungan positif yang signifikan antara minat siswa dengan pengetahuan sejarah lokal; (3) mendeskripsikan hubungan positif yang signifikan antara motivasi siswa dengan pengetahuan sejarah lokal; dan (4) mendeskripsikan hubungan positif yang signifikan antara sikap, minat, dan motivasi belajar dengan pengetahuan sejarah lokal siswa SD di Bandarlampung.

\section{METODE}

\section{Desain}

Penelitian survey yang dilakukan di Bandarlampung ini menggunakan desain deskriptif kuantitatif untuk menghubungkan variabel bebas yang terdiri dari Sikap $\left(X_{1}\right)$, Minat $\left(X_{2}\right)$, dan Motivasi $\left(X_{3}\right)$ dengan variabel terikat, yaitu Pengetahuan Sejarah Lokal (Y). Hubungan antar variabelnya dapat dilihat pada gambar 1 sebagai berikut.

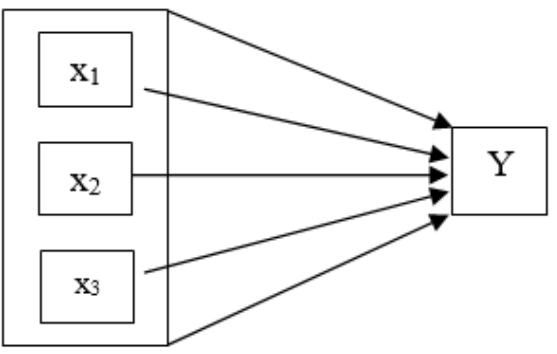

Gambar 1. Desain Penelitian

\section{Populasi dan Sampel}

Populasi dalam penelitian ini adalah siswa kelas V SD di Bandar Lampung. Sampel penelitian ini diambil dengan menggunakan purposive sampling. Sampel yang dipilih adalah SDN 2 Sumur Putri dan SDS Fajar Mulya, dengan sebaran siswa sebagai terlihat pada tabel 1 berikut.

Tabel 1. Sampel Penelitian

\begin{tabular}{lc}
\hline Subjek & Jumlah Sampel \\
\hline SDN 2 Sumur Putri & 21 \\
SDS Fajar Mulya & 32 \\
Jumlah & 53 \\
\hline
\end{tabular}

\section{Instrumen Penelitian}

Instrumen penelitian yang digunakan adalah angket dan tes, yaitu angket skala sikap, minat, dan motivasi serta tes pengetahuan sejarah lokal. Tes dilakukan pada data pengetahuan sejarah lokal dengan memberikan soal pilihan ganda, sedangkan untuk instrumen nontes dengan memberikan kuesioner tentang data sikap, minat, dan motivasi belajar.

Tabel 2. Kisi-kisi Indikator Angket Sikap

\begin{tabular}{|c|c|c|}
\hline No & Sub Variabel & Indikator \\
\hline \multirow[t]{2}{*}{1} & \multirow{2}{*}{$\begin{array}{l}\text { Sikap terhadap } \\
\text { tujuan dan isi } \\
\text { mata pelajaran } \\
\text { sejarah. }\end{array}$} & $\begin{array}{l}\text { Paham dan yakin } \\
\text { pentingnya tujuan } \\
\text { dan isi sejarah. }\end{array}$ \\
\hline & & $\begin{array}{l}\text { Kemauan } \\
\text { mempelajari } \\
\text { menerapkan } \\
\text { sejarah lokal. }\end{array}$ \\
\hline \multirow[t]{2}{*}{2} & \multirow[t]{2}{*}{$\begin{array}{l}\text { Sikap terhadap } \\
\text { pembelajaran } \\
\text { Sejarah Lokal. }\end{array}$} & $\begin{array}{l}\text { Keseriusan dalam } \\
\text { mempelajari Sejarah } \\
\text { Lokal. }\end{array}$ \\
\hline & & $\begin{array}{l}\text { Senang membaca } \\
\text { atau mempelajari } \\
\text { buku Sejarah. }\end{array}$ \\
\hline 3 & $\begin{array}{l}\text { Sikap terhadap } \\
\text { guru yang } \\
\text { mengajar } \\
\text { Seiarah Lokal. }\end{array}$ & $\begin{array}{l}\text { Cara mengajar guru } \\
\text { Sejarah Lokal. }\end{array}$ \\
\hline
\end{tabular}


Yulia Siska, Korelasi Sikap, Minat, dan Motivasi Belajar dengan Pengetahuan Sejarah...

$\begin{array}{lll}\text { Sikap siswa } & \text { Minat siswa belajar } \\ \text { terhadap } & \text { dengan } \\ \text { kegiatan } & \text { Aktivitas siswa selama } \\ \text { pembelajaran } & \text { pembelajaran }\end{array}$

Tabel 3. Kisi-kisi Minat Belajar

\begin{tabular}{lll}
\hline Aspek & Indikator & \\
\hline Minat & Dorongan untuk maju dan
\end{tabular}

belajar menekuni pelajaran sejarah (lokal).

Kemauan siswa dalam mengikuti pengajaran sejarah (lokal).

Perhatian terhadap segala kegiatan atau aktivitas yang berkaitan dengan pelajaran sejarah (lokal).

Tujuan atau orientasi siswa mempelajari sejarah (lokal).

Tabel 4. Kisi-kisi Kuesioner Motivasi Belajar

\begin{tabular}{|c|c|}
\hline \multirow{3}{*}{$\begin{array}{l}\text { Aspek } \\
\text { Kebutuhan } \\
\text { Dasar. }\end{array}$} & Indikator \\
\hline & Adanya \\
\hline & $\begin{array}{l}\text { kebutuhan dasar termasuk } \\
\text { kebutuhan fisiologis siswa } \\
\text { dalam proses belajar. }\end{array}$ \\
\hline \multirow{2}{*}{$\begin{array}{l}\text { Kebutuhan } \\
\text { akan rasa } \\
\text { aman. }\end{array}$} & $\begin{array}{l}\text { Kebutuhan rasa aman secara } \\
\text { fisik. }\end{array}$ \\
\hline & $\begin{array}{l}\text { Adanya pemenuhan } \\
\text { kebutuhan rasa aman secara } \\
\text { psikis. }\end{array}$ \\
\hline \multirow[t]{2}{*}{$\begin{array}{l}\text { Kebutuhan } \\
\text { rasa sayang } \\
\text { dan sosial. }\end{array}$} & $\begin{array}{l}\text { Adanya pemenuhan akan } \\
\text { rasa sayang dari orang tua, } \\
\text { teman, guru dan masyarakat } \\
\text { sekitar. }\end{array}$ \\
\hline & $\begin{array}{l}\text { Adanya perasaan diterima di } \\
\text { lingkungan sekitar. }\end{array}$ \\
\hline \multirow{2}{*}{$\begin{array}{l}\text { Kebutuhan } \\
\text { akan harga } \\
\text { diri dan } \\
\text { aktualisasi } \\
\text { diri. }\end{array}$} & $\begin{array}{l}\text { Adanya rasa kepercayaan } \\
\text { dan tanggung jawab dari } \\
\text { orang lain. }\end{array}$ \\
\hline & $\begin{array}{l}\text { Adanya rasa } \\
\text { mengembangkan } \\
\text { yang dimiliki. }\end{array}$ \\
\hline
\end{tabular}

Tabel 5. Kisi-kisi Tes Pengetahuan Sejarah lokal

\begin{tabular}{ll}
\hline Indikator & Topik/Tema \\
\hline & Adat istiadat \\
Pengetah & Tempat bersejarah \\
van & Kebiasaan dan falsafah hidup \\
sejarah & Cerita rakyat \\
lokal & Sistem pemerintahan (kerajaan, \\
& lembaga adat, keratuan)
\end{tabular}

\author{
Pahlawan dan kepahlawanan \\ Peristiwa sejarah lokal pada masa \\ kolonial. \\ Peristiwa sejarah lokal pada masa \\ perang kemerdekaan. \\ Peristiwa sejarah lokal \\ kontemporer. \\ Historiografi Lampung.
}

Untuk kepentingan uji coba instrumen diambil sebanyak 20 siswa yang masih berada pada satu populasi, yaitu siswa kelas V SDN 1 Gunung Terang, tetapi tidak termasuk ke dalam sampel penelitian.

Pengujian validitas instrumen penelitian ini diutamakan pada validitas rasio, yaitu construct validity (validitas bangun) dan content validity (validitas isi). Keempat instrumen telah diuji oleh validator internal dan dalam hal ini memperoleh hasil validitas yang dinyatakan layak untuk divjikan.

Perhitungan reliabilitas instrumen sikap terhadap pelajaran Sejarah Lokal, minat belajar Sejarah Lokal, dan motivasi belajar Sejarah Lokal yang bersifat nontes diuji dengan menggunakan teknik koefisien Alpha Cronboach. Sementara itu, instrumen pengetahuan sejarah lokal menggunakan rumus $K-R$ 20. Setelah dilakukan perhitungan reliabilitas dengan SPSS 16 menghasilkan nilai reliabilitas instrumen yang tinggi.

Tabel 6. Rangkuman Uji Reliabilitas

\begin{tabular}{lll}
\hline \multicolumn{2}{l}{ Reliability Statistics } \\
\hline Instrument & Cronbach's & \\
& Alpha & N of Items \\
Sikap & 0.722 & 20 \\
Minat & 0.782 & 20
\end{tabular}




\begin{tabular}{lll}
\hline \multicolumn{2}{l}{ Reliability Statistics } \\
\hline Instrument & Cronbach's & \\
& Alpha & N of Items \\
Motivasi & 0.963 & 20 \\
Pengetahuan & 0.577 & 20 \\
\hline
\end{tabular}

Rumus hipotesis penelitian dengan analisis regresis, yaitu regresi $X_{1}, X_{2}$, dan $X_{3}$ terhadap Y adalah:

$\mathrm{H}_{0}=\mathrm{b}_{1}=\mathrm{b}_{2}=0$

$\mathrm{H}_{1}=\mathrm{b}_{1}=\mathrm{b}_{2} \neq 0$

PEMBAHASAN

Hubungan Sikap Terhadap Pelajaran Sejarah Lokal dengan Pengetahuan Sejarah Lokal

Berdasarkan deskripsi data sikap siswa terhadap pelajaran sejarah lokal dapat diketahui bahwa interval yang mempunyai frekuensi terbanyak adalah pada interval 55-59 dengan jumlah frekuensi absolut 18, sedangkan frekuensi relatif sebesar 33,96\%. Jika subjek penelitian dibedakan menjadi dua bagian maka nilai rata-rata ideal berada pada angka 61 (dengan menjumlahkan skor tertinggi dengan terendah dibagi dua), siswa yang memiliki sikap terhadap pelajaran sejarah lokal tinggi adalah sejumlah 23 atau 43,40\%, sedangkan siswa yang memiliki Sikap rendah sejumlah 30 siswa atau $56,60 \%$. Jika dibedakan berdasarkan tiga kelompok skor ideal, sebaran data dapat dilihat pada tabel berikut.

Tabel 7. Distribusi Frekuensi Data Sikap terhadap Pelajaran Sejarah Lokal Berdasarkan Skor Ideal

\begin{tabular}{llllll}
\hline Interval & Kategori & F & Fr\% & FK & Frh\% \\
\hline $\begin{array}{l}69,46 \\
\text { ke atas }\end{array}$ & Tinggi & 2 & 3,77 & 30 & 56,60
\end{tabular}

\begin{tabular}{|c|c|c|c|c|c|}
\hline $\begin{array}{l}69,46- \\
52,54\end{array}$ & Sedang & 50 & 94,34 & & \\
\hline $\begin{array}{l}52,54 \\
\text { ke } \\
\text { bawah }\end{array}$ & Rendah & 1 & 1,89 & 23 & 43,40 \\
\hline
\end{tabular}

Berdasarkan tabel 7, siswa yang mempunyai sikap terhadap pelajaran sejarah lokal dengan kategori tinggi sebanyak $2(3,77 \%)$ dan $50(94,34 \%)$ siswa tergolong mempunyai sikap sedang, sementara $1(1,98 \%)$ siswa memiliki sikap terhadap pelajaran sejarah lokal yang rendah. Oleh sebab itu, sikap siswa terhadap pelajaran sejarah lokal berada pada kriteria sedang, yaitu (94,34\%) pada interval 69,46-52,54. Dengan demikian, dapat ditarik kesimpulan bahwa sikap siswa terhadap pelajaran sejarah lokal berada pada kategori sedang senilai $94,34 \%$ pada interval $69,46-$ 52,54 .

Hasil perhitungan pada hipotesis pertama $\left(\mathrm{H}_{1}\right)$ membuktikan bahwa tidak terdapat hubungan efektif antara sikap terhadap pelajaran sejarah lokal dengan pengetahuan sejarah lokal siswa kelas $\mathrm{V}$ SD di Bandarlampung. Hal ini dibuktikan dengan hasil analisis regresi tiga prediktor, yaitu $0,523 \quad(p>0,05)$. Maka dari itu, hipotesis ditolak. Dengan demikian, dapat disimpulkan bahwa tidak ada hubungan positif yang signifikan antara sikap terhadap pelajaran sejarah lokal dengan pengetahuan sejarah lokal siswa. Tidak adanya hubungan antara sikap dengan pengetahuan sejarah lokal tersebut berbeda dengan yang diungkap oleh 
Yulia Siska, Korelasi Sikap, Minat, dan Motivasi Belajar dengan Pengetahuan Sejarah...

Handayani (2008, p.117) yang menemukan adanya hubungan positif yang signifikan antara sikap dengan prestasi belajar. Begitu pula Azwar (2012, p. 23) menyebutkan bahwa struktur sikap yang terdiri dari tiga komponen saling menunjang, salah satunya adalah komponen kognitif sebagai representasi apa yang dipercayai oleh individu pemilik sikap. Oleh sebab itu, hipotesis tidak terbukti.

\section{Hubungan antara Minat terhadap Pelajaran Sejarah Lokal dengan Pengetahuan Sejarah Lokal Siswa SD di Bandarlampung}

Berdasarkan deskripsi data minat terhadap pelajaran sejarah lokal dapat diketahui bahwa kelompok skor dengan frekuensi terbanyak adalah pada interval 55-59 dengan jumlah frekuensi absolutnya adalah 20 dan frekuensi relatif sebesar $37,74 \%$. Jika subjek penelitian dibedakan menjadi dua bagian maka nilai rata-rata ideal berada pada angka 61 (dengan menjumlahkan skor tertinggi dengan terendah dibagi dua), siswa yang memiliki minat terhadap pelajaran sejarah lokal tinggi sejumlah 18 siswa atau $33,96 \%$ dan siswa yang mempunyai minat terhadap pelajaran sejarah lokal rendah sejumlah 35 siswa atau 66,04\%. Jika dibedakan berdasarkan tiga kelompok skor ideal, sebaran data dapat dilihat pada tabel berikut.
Tabel 8. Distribusi Frekuensi Data Minat terhadap Pelajaran Sejarah Lokal Berdasarkan Skor Ideal

\begin{tabular}{llllll}
\hline Interval & Kategori & $\mathrm{F}$ & $\mathrm{Fr} \%$ & $\mathrm{FK}$ & Frh\% \\
\hline $\begin{array}{l}68,86 \\
\text { ke atas }\end{array}$ & Tinggi & 5 & 9,43 & 35 & 66,04 \\
$\begin{array}{l}68,86- \\
53,14\end{array}$ & Sedang & 45 & 84,91 & & \\
$\begin{array}{l}53,14 \\
\text { ke } \\
\text { bawah }\end{array}$ & Rendah & 3 & 5,66 & 18 & 33,96 \\
\hline
\end{tabular}

Dari tabel 8 dapat diketahui bahwa siswa yang mempunyai minat terhadap pelajaran sejarah lokal dengan kategori tinggi sebanyak $5(9,43 \%)$ dan $45(84,91 \%)$ siswa termasuk memiliki minat sedang, sementara $3(5,66 \%)$ siswa berada dalam kategori rendah. Dengan demikian, minat siswa terhadap pelajaran sejarah lokal berada pada kategori sedang, yaitu $(84,91 \%)$ pada interval 68,86-53,14. Dapat ditarik simpulan bahwa minat siswa terhadap pelajaran sejarah lokal berada pada kategori sedang sebesar $84,91 \%$ pada interval 68,86-53,14.

Hasil pengujian hipotesis pertama $\left(\mathrm{H}_{2}\right)$ terbukti bahwa tidak terdapat hubungan efektif antara minat siswa terhadap pelajaran sejarah lokal dengan pengetahuan sejarah lokal siswa kelas $\mathrm{V}$ SD di Bandarlampung. Hal ini dibuktikan dengan hasil analisis regresi tiga prediktor, yaitu $0,470 \quad(p>0,05)$. Maka dari itu, hipotesis ditolak. Dengan demikian, dapat disimpulkan bahwa tidak terdapat hubungan positif dan signifikan antara minat terhadap pelajaran sejarah lokal dengan pengetahuan sejarah lokal siswa. 
Temuan penelitian ini memiliki ketimpangan dengan teori yang menyatakan bahwa ada hubungan positif yang signifikan antara minat dengan prestasi belajar. Minat adalah kecenderungan tingkah laku yang mengarah pada tujuan yang pasti, aktivitas-aktivitas atau pengalaman yang menarik dari tiap individu. Oleh karena itu, apabila individu atau seseorang menaruh minat terhadap sesuatu, berarti telah menetapkan tujuan sebelumnya (Handayani, 2008, p. 117). Sedangkan, Saifullah (2009, p. 97) dalam penelitiannya menemukan adanya indikasi bahwa minat belajar tidak memiliki pengaruh terhadap prestasi belajar.

Hubungan antara Motivasi Belajar Sejarah Lokal dengan Pengetahuan Sejarah Lokal Siswa SD di Bandarlampung

Berdasarkan deskripsi data Motivasi Belajar Sejarah Lokal dapat diketahui bahwa kelompok yang mendapat frekuensi terbanyak adalah pada interval 56-59 dengan jumlah frekuensi absulut 22 dan frekuensi relatif sebesar ,60\%. Jika dibedakan menjadi dua berdasarkan rerata ideal sebesar 60,5 (dengan menjumlahkan skor tertinggi dengan skor terendah dibagi dua), siswa yang memiliki motivasi belajar sejarah lokal yang tinggi sejumlah 20 siswa atau $37,74 \%$. Sedangkan siswa yang mempunyai motivasi belajar sejarah lokal rendah sejumlah 33 siswa atau $62,26 \%$. Jika dibedakan berdasarkan tiga kelompok skor ideal, sebaran data dapat dilihat pada tabel berikut.

Tabel 9. Distribusi Frekuensi Data Motivasi Belajar Sejarah Lokal Berdasarkan Skor Ideal

\begin{tabular}{llllll}
\hline Interval & Kategori & F & Fr\% & FK & Frh\% \\
\hline $\begin{array}{l}67,08 \mathrm{ke} \\
\text { atas }\end{array}$ & Tinggi & 4 & 7,55 & 33 & 62,26 \\
$\begin{array}{l}67,08- \\
53,91\end{array}$ & Sedang & 45 & 84,91 & & \\
$\begin{array}{l}53,91 \mathrm{ke} \\
\text { bawah }\end{array}$ & Rendah & 4 & 7,55 & 20 & 37,74 \\
\hline
\end{tabular}

Dari tabel 9 dapat diketahui bahwa siswa yang mempunyai motivasi belajar sejarah lokal dengan kategori tinggi sebanyak siswa yang mempunyai motivasi belajar yang tinggi adalah 4 (7,55\%) dan 45 $(84,91 \%)$ siswa tergolong mempunyai motivasi belajar yang sedang, sementara $4(7,55 \%)$ siswa tergolong rendah. Dengan demikian, dapat disimpulkan bahwa motivasi belajar sejarah lokal siswa berada pada kategori sedang, yaitu $(84,91 \%)$ pada interval 67,08-53,91.

Hasil pengujian hipotesis pertama $\left(\mathrm{H}_{3}\right)$ membuktikan bahwa ada hubungan efektif antara motivasi belajar sejarah lokal dengan pengetahuan sejarah lokal siswa kelas V SD di Bandarlampung. Hal ini dibuktikan dengan hasil analisis regresi tiga prediktor, yaitu $0,017(p<0,05)$. Maka dari itu, hipotesis diterima. Dengan demikian, dapat disimpulkan bahwa ada hubungan positif yang signifikan antara motivasi belajar sejarah lokal dengan pengetahuan sejarah lokal siswa. 
Yulia Siska, Korelasi Sikap, Minat, dan Motivasi Belajar dengan Pengetahuan Sejarah...

Hasil penelitian sesuai dengan hasil penelitian sejenis yang pernah dilakukan, yaitu ada pengaruh yang positif dan signifikan antara motivasi belajar terhadap prestasi belajar (Bimantara, 2017, p. 1-11). Motivasi belajar memiliki hubungan positif terhadap prestasi belajar dengan kriteria hubungan sedang. Jika motivasi belajar baik maka prestasi belajar akan baik.

\section{Hubungan antara Sikap terhadap Pelajaran Sejarah Lokal, Minat terhadap Pelajaran Sejarah Lokal, dan Motivasi Belajar Sejarah Lokal dengan Pengetahuan Sejarah Lokal Siswa SD di Bandarlampung}

Berdasarkan deskripsi data pengetahuan sejarah lokal, diketahui bahwa kelompok yang mempunyai frekuensi terbanyak berada pada interval 17-19 dengan jumlah frekuensi absolut sebenyak 23 dan frekuensi relatif $43,40 \%$. Jika subjek penelitian dibedakan menjadi dua bagian maka nilai rata-rata ideal berada pada angka 19 (dengan menjumlahkan skor tertinggi dengan terendah dibagi dua), siswa yang memiliki pengetahuan sejarah lokal dengan kategori tinggi sebanyak 17 siswa atau 32,08\% dan siswa yang memiliki pengetahuan sejarah lokal dengan kategori rendah sebanyak 36 siswa atau 67,92\%. Jika dibedakan berdasarkan tiga kelompok skor ideal, sebaran data dapat dilihat pada tabel berikut.
Tabel 10. Distribusi Data Pengetahuan Sejarah Lokal Berdasarkan Skol Ideal

\begin{tabular}{llllll}
\hline Interval & Kategori & $\mathrm{F}$ & $\mathrm{Fr} \%$ & $\mathrm{FK}$ & Frh\% \\
\hline $\begin{array}{l}22,84 \\
\text { ke atas }\end{array}$ & Tinggi & 2 & 3,77 & 17 & 32,08 \\
$\begin{array}{l}22,84- \\
15,16\end{array}$ & Sedang & 42 & 79,25 & - & - \\
$\begin{array}{l}15,16 \\
\text { ke }\end{array}$ & Rendah & 9 & 16,98 & 36 & 67,92 \\
bawah & & & & & \\
\hline
\end{tabular}

Berdasarkan tabel tersebut, tampak bahwa siswa yang memiliki pengetahuan sejarah lokal dengan kategori tinggi adalah 2 (3,77\%) dan $42(79,25 \%)$ siswa tergolong mempunyai pengetahuan sejarah lokal yang sedang, sementara 9 $(16,98 \%)$ siswa tergolong rendah pengetahuan sejarah lokalnya. Oleh sebab itu, dapat disimpulkan bahwa pengetahuan sejarah lokal siswa berada pada kategori sedang, yaitu 79,25\% pada interval 22,84-15,16.

Hasil pengujian hipotesis kedua $\left(\mathrm{H}_{4}\right)$ membuktikan bahwa terdapat pengaruh positif antara sikap, minat, dan motivasi belajar sejarah lokal secara bersamasama terhadap pengetahuan sejarah lokal siswa kelas $V$ SD di Bandarlampung. Hipotesis tersebut dibuktikan dengan nilai tabel uji statistik F. Diketahui bahwa nilai F hitung lebih besar dari F tabel (signifikan), yaitu $9.169>2,79$ pada taraf koefisiensi $5 \%$ dengan $\mathrm{db}$ pembilang 3 dan $\mathrm{db}$ penyebut 49. Adapun persamaan garis regresinya adalah $Y=0,087 X_{1}-0,102 X_{2}+$ 0,354 $X_{3}-2,109$ yang berarti kenaikan skor sikap terhadap pelajaran sejarah lokal, minat terhadap pelajaran sejarah lokal, 
dan motivasi belajar sejarah lokal signifikan untuk memprediksi peningkatan terhadap pengetahuan sejarah lokal siswa kelas V SD di Bandarlampung.

Temuan di atas sesuai dengan hasil penelitian yang dilakukan oleh Handayani (2008), yaitu terdapat hubungan positif dan signifikan antara pengetahuan, sikap, minat, motivasi belajar dengan prestasi belajar mata kuliah KDM I pada mahasiswa semester I Akper Giri Satria Husada Wonogiri. Begitu pun dengan kajian yang dilakukan oleh Jainuri (2015) memperoleh hasil serupa. Dengan demikian, faktor dalam diri siswa tentunya memiliki peranan yang lebih dominan dibandingkan faktor dari luar disi siswa, walaupun asumsi ini tidak didukung oleh fakta atau data empiris. Faktor dari dalam (minat, motivasi, dan sikap) adalah hal yang lebih diperlukan dalam belajar, bukan berarti faktor dari luar tidak penting, misal metode, sarana dan prasarana, strategi belajar, dan sebagainya (Kartadinata, 2010, p. 3; Winkel, 1983, p. 30; Azwar, 2012, p. 28). Dalam konteks penelitian ini, faktor dari diri siswa, di dalamnaya termasuk sikap, minat, dan motivasi sebagaimana telah disebutkan memiliki kedudukan khusus dalam mempengaruhi pemahaman sejarah lokal siswa.

\section{SIMPULAN}

Berdasarkan data yang diperoleh dari hasil penelitian dan analisis statistik, simpulan yang dapat dikemukakan sebagai berikut: (1) tidak terdapat hubungan positif yang signifikan antara sikap terhadap pelajaran sejarah lokal $\left(X_{1}\right)$ dengan pengetahuan sejarah lokal (Y) siswa kelas $V$ SD di Bandarlampung. Hal ini dibuktikan dengan hasil analisis regresi tiga prediktor, yaitu $0,523(p>0,05)$. Maka dari itu, hipotesis ditolak; (2) tidak terdapat hubungan positif yang signifikan antara minat terhadap pelajaran sejarah lokal $\left(X_{2}\right)$ dengan pengetahuan sejarah lokal (Y) siswa kelas $V$ SD di Bandarlampung. Hal ini dibuktikan dengan hasil analisis regresi tiga prediktor, yaitu 0,470 (p>0,05). Maka dari itu, hipotesis ditolak; (3) terdapat hubungan positif yang signifikan antara motivasi belajar sejarah lokal $\left(X_{3}\right)$ dengan pengetahuan sejarah lokal $(Y)$ siswa kelas $\checkmark \mathrm{SD}$ di Bandarlampung. Hal ini dibuktikan dengan hasil analisis regresi tiga prediktor, yaitu $0,017 \quad(p<0,05)$. Maka dari itu, hipotesis diterima; dan (4) terdapat hubungan positif yang signifikan antara sikap $\left(X_{1}\right)$, minat $\left(X_{2}\right)$, dan motivasi belajar sejarah lokal $\left(X_{3}\right)$ secara bersama-sama terhadap pengetahuan sejarah lokal $(Y)$ siswa kelas $\vee$ SD di Bandarlampung. Hal ini dibuktikan dengan hasil perhitungan analisis regresi dan dibandingkan dengan tabel F. Diketahui bahwa nilai $F$ hitung lebih besar dari $\mathrm{F}$ tabel, yaitu 9,169 $>2,79$ pada taraf koefisiensi $5 \%$ dengan $\mathrm{db}$ pembilang 3 dan $\mathrm{db}$ penyebut 49 . Persamaan garis regresi: $Y=0,087 X_{1}-$ $0,102 X_{2}+0,354 X_{3}-2,109$. 
Yulia Siska, Korelasi Sikap, Minat, dan Motivasi Belajar dengan Pengetahuan Sejarah...

\section{REFERENSI}

Abdullah, T. (2010). Sejarah Lokal di Indonesia. Yogyakarta: Gadjah Mada University Press.

Astuti, B. (2017). Meningkatkan Motivasi dan Hasil Belajar IPS Siswa Kelas VI SD melalui Model Group Investigation. Mimbar Sekolah Dasar, $4(3)$, 264-271. doi:http://dx.doi.org/10.17509/mimba r-sd.v4i3.7843.

Azwar, S. (2012). Sikap Manusia: Teori Dan Pengukurannya. Yogyakarta: Pustaka Pelajar.

Bimantara F., W. (2017). Hubungan Sikap Dan Motivasi Belajar Dengan Prestasi Belajar IPS Terpadu Siswa Kelas VIII. Jurnal Ilmu Pendidikan, 7, 1-11.

Dimyati. (2002). Belajar Pembelajaran. Jakarta: Rineka Cipta.

Effendy, O. U. (2003). Ilmu Komunikasi Teori dan Praktek. Bandung: Rosda Karya.

Handayani, S. (2008). "Hubungan pengetahuan, sikap, minat dan motivasi belajar dengan prestasi belajar mata kuliah KDM I pada Mahasiswa Semester I Akper Giri Satria Husada Wonogiri". Tesis. Surakarta: PPs UNS.

Hasan, H. S. (1997). "Kurikulum dan Buku Teks Sejarah" dalam Kongres Nasional Sejarah 1996 Jakarta Sub Tema Perkembangan Teori dan Metodologi dan Orientasi Pendidikan Sejarah." Jakarta: Proyek Inventarisasi dan Dokumentasi Sejarah Nasional Direktorat Jenderal Kebudayaan Departemen Pendidikan dan Kebudayaan.

Hizam, I. (2007). Kontribusi Minat Belajar dan Kemampuan Klarifikasi Nilai Sejarah dalam Pembentukan Sikap Nasionalisme. Jurnal Penelitian Keis/aman, 3(2).

Jainuri, M. (2015). "Korelasi Sikap dan Minat dengan Motivasi Belajar Statistika Inferensial Mahasiswa Pendidikan Matematika". Laporan Penelitian. Bangko: Pendidikan Matematika STKIP YPM Bangko.
Kartadinata, S. (2010). Psikologi Anak Luar Biasa. Jakarta: Departemen. Pendidikan dan Kebudayaan.

Krug, M. M. (1967). History and the Social Sciences. Walthan Mass: Braisdell.

Lightman, A. J., \& French, V. (1978). Historians and The Living Past, The Theory and Practice of Historical Study. Arlington Heights: Harlan Davidson.

Priyadi, S. (2012). Sejarah Lokal Konsep, Metode dan Tantangannya. Yogyakarta: Penerbit Ombak.

Purwanto, N. (2006). Psikologi Pendidikan. Bandung: Remaja Rosdakarya.

Ruslaeni, dkk. (2013). "Pengaruh Minat Belajar, Gaya Mengajar dan Sikap Disiplin terhadap Prestasi Belajar Siswa Kelas VI Sekolah Dasar di Gugus Kartini Kecamatan Wonosobo". Jurnal Sainteks, 10(1), 72-97.

Saifullah, A. (2009). 'Pengaruh Sikap, Minat Dan Motivasi Belajar Terhadap Prestasi Bahasa Arab Kelas IV SD Muhammadiyah Sapen Yogyakarta". Thesis. UIN Sunan Kalijaga Yogyakarta.

Sudjana, N. (2005). Metoda Statistika (Edisi Ketiga). Bandung: Penerbit Tarsito.

Sukmadinata, N. S., \& Muhammad S. (1978). Pengantar Psikologi. Bandung: IKIP Bandung.

Supardi. (2006). Pendidikan Sejarah Lokal Dalam Konteks Multikulturalisme. Cakrawala Pendidikan, XXV (1), 117137.

Supardi. (2014). Pendidikan Multikultural Dalam Pembelajaran Sejarah Lokal. Jurnal Pembangunan Pendidikan: Fondasi dan Aplikasi, 2(1), 91-99.

Widja, I. G. (1989). Sejarah Lokal Suatu Perspektif dalam Pengajaran Sejarah. Jakarta: Depdikbud.

Winkel. W. (1983). Psikologi Pendidikan dan Evaluasi Belajar. Gramedia: Jakarta. 